DOI 10.18551/rjoas.2021-08.19

\title{
PLANNING OF SAMARINDA SMART CITY PROGRAM COMMUNICATION
}

\author{
Arsyad Annisa Wahyuni \\ Department of Communication Science, Faculty of Political and Social Science, \\ Mulawarman University, Indonesia \\ Noor Muhammad ${ }^{*}$ \\ Department of Government Science, Faculty of Political and Social Science, \\ Mulawarman University, Indonesia \\ Boer Kheyene Molakandella \\ Department of Communication Science, Faculty of Political and Social Science, \\ Mulawarman University, Indonesia \\ *E-mail: muhammadnoor@fisip.unmul.ac.id
}

\begin{abstract}
The population is getting longer experience. The increase due to population migration from one area to another and population growth not accompanied by good quality land will cause other problems such as social problems, environmental problems, high birth rates, and high poverty rates. Intensively make a design concept to overcome the problems that exist in urban areas, the design concept is Smart City, this concept arises because of the development of information and communication technology that cannot be evaded again, this concept can realize community and environment become more effective and efficient, this concept includes services, planning, and public policymaking. Samarinda is one of the cities that apply the Smart City concept, which is combined, can solve the problems in the city of Samarinda; this study aims to explain the importance of communication planning for the Smart City concept in Samarinda City. This study uses a qualitative descriptive method with five sources who own. In addition, although the efforts made by the Government are by the existing design, the implementation of this program has not been optimal; this is due to the lack of socialization of the program to the wider community and has not received APBD support, which will build infrastructure in the Smart City concept in Samarinda City.
\end{abstract}

\section{KEY WORDS}

Communication planning, smart city, socialization media, government.

The population has increased from year to year. The increase in population occurs naturally or because of population migration from one area to another. In addition, there is a change in urban characteristics from agricultural to urban characteristics (or what is commonly referred to as urban areas), and adequate land resources do not accompany this change. According to data from the Central Statistics Agency (BPS), it is predicted that $56.7 \%$ of the population living in urban areas will be in 2020 , and this number will increase to $66.6 \%$ in 2035. Population growth that is not accompanied by this land resource creates various urban problems and challenges. Such as population density, poverty, social and security problems, environmental problems, urban disparities, low competitiveness, underdevelopment of the city's local economy, quality of human resources, and various other problems. This, if left unchecked, will lead to an unhealthy city, and this needs a solution to overcome this problem.

Many concepts are designed to overcome urban problems, one of which is seen from the development of communication and information technology; this concept is referred to as Smart City. Smart City is the end of developing the concept of sustainable development and city management based on information and communication technology (Deakin \& Allwinkle, 2007) (Riyanto \& Mustofa, 2017: 23). The concept of Smart City emerged because of the 
development of information and communication technology that brought significant changes in human life. Information technology civilization has also entered the era of digitalization, which has caused changes in the pattern of society, from modern society to a digital society. This is what gave rise to the idea of creating community governance (including urban communities who are considered more prepared than rural communities). Smart City is seen as a regional development strategy and a new style of city management.

The concept of Smart City or Smart City began to be applied in various cities of developed countries since the beginning of the new millennium ago. This phenomenon cannot be separated from the existence of the internet through the world wide web feature, which was initially only used among governments and academics, which later developed rapidly and became a medium of communication and mass transactions in different lives (Coe et al., 2001) in (Nuzir, 2015:1). ) another definition, according to Dameri (2013) in (Nuzir, 2015:2) states that a smart city is a certain geographical area where advanced technologies such as ICT, logistics, energy production, and others complement each other to create benefits for city residents related to welfare, participation, environmental quality, intellectual development, orderly governance with various good policies.

In Indonesia, the Smart City concept was initiated by the Professor of STEI ITB, Prof. Dr. Ir. Suhono S. Supangkat. According to him, a smart city is a solution for its citizens, consisting of components of a smart economy, smart people, smart governance, smart Government, smart mobility, smart environment, and smart living._Several cities in Indonesia have started implementing the Smart City concept in recent years. Jakarta launched the "Jakarta Smart City" program in 2015. Residents can access the smart city.Jakarta.go.id portal. The existence of this program is claimed to be able to facilitate the performance of the provincial government officials in responding quickly to citizen complaints. In addition, this portal is used to monitor traffic management, flood problems, and garbage trucks. The portal is made in a two-way communication flow to convey their aspirations through rail time complaints.

In addition, the Surabaya City Government has also implemented various Smart City program innovations, such as E-Health services (registration service applications at health centers and hospitals), e-Kios (applications to facilitate licensing services), Solid Waste Transportation (SWAT), or other systems. Waste management is one of the big cities in East Kalimantan that applies the concept of a Smart City to Samarinda City. The city of Samarinda was chosen to be one of the cities that participated in the "Movement Towards 100 Smart Cities Indonesia" Program. This program is carried out by following an assessment that refers to the dimensions of policy, human resources in the field of ICT, ICT infrastructure, applications that include public services, general administration and management, legislative administration, development management, financial management, personnel management and commitment to budget support. Based on letter number 265/KOMINFO/DJAI/AI.01.05/05/2017 dated May 5, 2017, Samarinda was declared to have passed to join the program regarding the submission of assessment selection results.

The Samarinda City Government has made a 2017-2025 Samarinda Smart City master plan. The preparation of this master plan has the aim of providing direction for accelerating the development strategies, policies, and programs of the City of Samarinda, which have been contained in the Development Planning Documents such as the Medium Term Development Plan (RPJP) for 2016-2021, the Long Term Development Plan (RPJP) for 2005-2025 and Regional Spatial Plan (RTRW) of Samarinda City 2014-2034. This program aims to make Samarinda a livable city, especially for future generations. In 2021, it is hoped that the City of Samarinda can become a Metropolitan City that is competitive and environmentally friendly. By 2025, the City of Samarinda can become a leading Edge City in Kalimantan. Then, by 2034 it will become a Frontier City based on advanced trade, services, and industry, environmentally and green, and has competitive advantages to improve people's welfare. (Masterplan Samarinda Smart City 2017-2025)

According to Rogers in Canada (2013: 33), communication is a process in which an idea is transferred from a source to a recipient or more to change their behavior. In addition, Effendy (2013:10) explains that communication can be carried out effectively by asking the 
question, "Who Says What In Which Channel To Whom With What Effect?" said Harold Laswell. The Lasswell paradigm shows that communication includes five elements in response to the question, namely: (1) communicator (communicator, source, sender), (2) message (message), (3) media (channel, media), (4) Communicant (communicant, communicatee, receiver, recipient), (5) Effect (effect, impact, influence).

The communication process is divided into two, namely, the primary and secondary communication processes. The primary communication process conveys one's thoughts and feelings to others by using symbols as a medium. While the secondary communication process is delivering messages by one person to another using a tool or means as a second medium after using a symbol as the first medium. (Effendy, 2013: 16). according to Fajar (2009: 60), there are four communication goals, namely: Attitude change, Opinion change, Behavior Change, and Social Change. This communication planning concept appears to link the plans that have been made by combining all the elements of communication. According to (Cangara 2013: 41), communication planning is intended to overcome existing obstacles to achieve communication effectiveness, while in terms of the usefulness and function of communication planning to implement programs to be achieved both campaign activities, counseling, imaging, social marketing, and commercial, as well as for the construction of communication infrastructure.

Smart City is a global issue that is currently booming. IBM first coined Smart City in 1998 , but Smart City was only developed in the 2000s. The basic concept of a Smart City is to create a community/environment for a society that is efficient, sustainable, and provides a sense of security. The Smart City concept includes services, public policy formulation, and planning; this is as stated by Patel \& Padhya (2014) in Annisah (2017:60)

Smart City is the result of intensive scientific development with creative strategies to improve cities' socio-economic, ecological, and competitive power. The smart city results from a combination of human capital, infrastructure capital, social capital, and entrepreneurial capital. A strong and trustworthy government and the support of creative people have a role in increasing local productivity and accelerating the economic growth of a city. with this background, it is clear how important Smart City communication planning is in Samarinda City, and this research will examine planning from a management approach. In contrast, communication relates to the process of disseminating or exchanging information.

\section{METHODS OF RESEARCH}

This research is qualitative research with a descriptive method. Qualitative research is explored and deepened from a social phenomenon or social environment consisting of actors, events, places, and times. In qualitative research, researchers want to explore descriptive phenomena that cannot be quantified. There is a clear description regarding the stages of communication planning in the Samarinda Smart City program through this research method. In addition, through this research, the factors supporting and inhibiting communication in the Samarinda Smart City planning program can be seen.

This research was conducted at the Department of Communication and Information of Samarinda City. This research is scheduled to be conducted in August - September 2019. This study uses informants who are considered competent people to provide the required data in taking the sample.

Primary data is data obtained directly from the field, either through observation or through interviews with informants. The primary data collection method is carried out by direct interviews with parties from the Samarinda City Government. They are involved in the planning process of the Samarinda City Smart City Program.

Key informants in this study are parties who know and are related to the concept, direction of planning policies, and how the Samarinda Smart City is implemented.

The informants in this study are parties who have an important role in the Samarinda Smart City Program:

1. Mr. Suparmin, SE, M.Eng (Head of Applications and E-Services)Government Samarinda City Communications and Information Office); 
2. Mr. Hendri Gunawan, S.Kom (Head of Sub-Division of Telecommunication and Electricity, Regional Development Planning Agency of Samarinda City);

3. Novy Mediani (Business Actors, Owner Brand Jukut). Jukut is one of the local fashion brands known in Samarinda;

4. Dr. Rina Juwita, S.IP, M.HRIR (Academic / Lecturer in Communication Studies Program);

5. Catur Mayyulinda, SIKom (Journalist from East Kalimantan Pos Group and Graduate from Communication Studies Program).

Secondary data, namely in the form of documents or literature, or reports from the Samarinda City Government regarding the relocation of the Karang Mumus River, the internet, newspapers, journals, and other references, can support research.

In writing this study, researchers used several ways to collect the necessary data. Therefore, the researcher uses data collection techniques that are by this research, namely Field Research. Field Research in field research where researchers try to obtain data and information by conducting direct observations with the object under study by:

- Observation is direct observation of an object under study to determine the object's existence, situation, context, and meaning to collect research data. (Satori \& Komariah, 2014:105) In the context of qualitative research, observation is not to test the truth but to find out the truth related to aspects/categories as aspects of studies developed by researchers;

- Interviews were conducted in an open and structured manner with questions focused on problems so that the information collected was quite complete and in-depth. The interview guide was prepared based on the research focus, which was related to the communication planning of the Smart City program in Samarinda City;

- Data collection is carried out to obtain secondary data in the form of documents or archives regarding the Samarinda City Smart City Program such as the Samarinda Smart City Master Plan, Blue Samarinda Smart City, Mayor Regulation no. 08 of 2018 Regarding the Samarinda Smart City Masterplan, various news sources, as well as all forms of documentation of events, events related to the problems to be investigated.

\section{RESULTS AND DISCUSSION}

The city of Samarinda is the capital of the province of East Kalimantan. Based on Government Regulation No. 21 of 1987 concerning the Determination of Regional Boundaries for the Second Level Municipality of Samarinda, it is astronomically located at a position between 1703'00" - 117018'14" East Longitude and 00019'02" - 00042'34" South Latitude with an area of $718 \mathrm{~km}^{2}(71,800$ hectares) and is directly adjacent to Kutai Kartanegara. The Mahakam River, which divides the city of Samarinda, makes this city a gateway to the interior of East Kalimantan, namely to the surrounding districts such as East Kutai, West Kutai, Kutai Kartanegara, and other districts. Based on Regional Regulation Number 2 of 2014 concerning the Regional Spatial Planning of the City of Samarinda for the period 2014-2034, the City of Samarinda has a spatial planning goal, namely to realize Samarinda City into a Frontier City based on advanced trade, services, and industry, environmentally and green, and have a competitive advantage to improve the welfare of society.

The Edge City concept is a big concept that is not only the motto of the City of Samarinda. The edge itself is an acronym for Teduh, Neat, Safe, and Comfortable. Through the concept of the City of Edge, it can be a reflection of the City of Samarinda, which is located on the banks of the Mahakam River.

Based on this description, in the long term Waterfront City Development is very appropriate to be developed in Samarinda City to achieve spatial planning objectives, namely the development of the Mahakam Riverbank area and its main tributaries, namely the Karang Mumus River, Karang Asam Kecil River, and Karang Asam Besar River; and its tributaries to become waterfront tourism as one of the priority areas (strategic) for the development of 
Samarinda City in the next 20 years based on advanced trade, services, and industry, environmentally and green, and has competitive advantages. The purpose of the realization of Smart City is to make Samarinda City a liveable city, especially for future generations, through optimizing various things such as smart living, smart society, smart governance, smart economy, smart city branding, and smart environment. To achieve a smart city, the City of Samarinda must continue to pay attention to sustainable development.

In 2021, Samarinda City is expected to be able to achieve "The Realization of Samarinda City as a Competitive and Environmentally Friendly Metropolitan City", by 2025, it can "Realize Samarinda as a Leading Edge City in Kalimantan", and in 2034, "Samarinda City becomes a suburban city based on advanced trade, services, and industry, environmentally friendly and green, and has a competitive advantage to improve people's welfare. In the third phase of the 2016-2021 development direction of Samarinda City, based on the development theme that is carried out, namely "Consolidating Regional Leading Sector With Sustainable Development", Samarinda City places the trade, hotel, and restaurant sector as the leading sector in the city's economy, and is supported by the industrial sector and services. At this stage, the smart city concept began to be applied.

Samarinda's Smart City Vision: "The realization of Samarinda as the leading Smart Edge City in Kalimantan". The meaning of Smart Edge is related to the strong determination of the Samarinda City government in integrating the identity of the city and the meaning of the word Edge with the pillars of the Smart City. The city of Samarinda must be willing and able to solve all problems through the six pillars of a smart city, namely smart governance, smart branding, smart economy, smart living, smart society, and the smart environment, by prioritizing city identity.

The Leading Meaning is also a strong hope to make Samarinda the best city in Kalimantan regional level capable of realizing life democratic, creating superior human resources and superior culture, and visionary leaders to increase regional competitiveness. Overall, there are several targets for this Smart City program, which are as follows (Masterplan Samarinda Smart City, 2017:14): Implementation of flood control and relocation of SKM edges, Increased capacity and distribution of clean water, Achieving cleanliness, beauty, and an environmentally friendly city (parks and green open space), The realization of quality, transparent, accountable and corruption-free public services, Increased revenue and effective, efficient and accountable regional financial management, Increasing the economy through the role of MSMEs and cooperatives, tourism and creative economy, agriculture, plantations, animal husbandry, and fisheries, as well as other business services, Increasing the economy through private investment and traditional markets, Increasing quality education, Increasing school facilities and infrastructure as well as Facilitation for students from underprivileged families in Islamic boarding schools.

Based on the results of interviews with Mr. Suparmin, SE, M.Eng (Head of Applications and E-ServicesGovernment Samarinda City Communications and Information Office). Regarding the vision and mission of the Smart City Samarinda Program on September 3, 2019, it was stated that the long-term objective of the Smart City is to realize Samarinda as a smart and leading-edge city in the Kalimantan region, such as improving the quality of life, making Samarinda a livable city, and increasing satisfaction. Public. Explanation from Mr. Hendri Irawan, S.Kom (Head of Sub-Division of Telecommunication and Electricity at the Regional Development Planning Agency of Samarinda City) He stated that the Smart City concept should be implemented in Samarinda City because this is a necessity. Samarinda City is ready to make it happen because judging from the electronic-based government system, all networks are connected from the city government from the village; Samarinda already has an E-Kelurahan, a web version of E-Warga an Android version has been developed.

After being designated as one of the pilot cities in 2017, the next target is to make the Samarinda Smart City Master Plan created in 2017 and establish the Quick Win Samarinda Smart City program in 2018. In this case, there are two Quick Win programs. Win Samarinda Smart City 2018, namely the integration of public services and the revitalization of the Citra Niaga area. Catur Mayyulinda stated the same thing as a journalist for East Kalimantan Pos 
Group. In this case, the informant stated that the Samarinda City Smart City Program targets are the Government and the community as a whole. Conceptually, there is no problem with the Samarinda Smart City Program; all planning is carried out properly according to the principle of integrating communication technology with people's lives. In Samarinda, to support the Smart City program, there are many forums. The Samarinda City Smart City Forum is an investor forum for Quick Win Citra Niaga, a Go Online UMKM forum. This forum invites many parties who are the target audience for the program.

Table 1 - Quick win Samarinda Smart City Program

\begin{tabular}{|c|c|c|c|c|}
\hline No & Smart City Pillar & Work program & Aim & Target \\
\hline 1 & $\begin{array}{c}\text { Smart } \\
\text { Governance }\end{array}$ & $\begin{array}{l}\text { Public service } \\
\text { integration }\end{array}$ & $\begin{array}{l}\text { Improving the quality } \\
\text { of local government } \\
\text { governance }\end{array}$ & $\begin{array}{l}\text { Realization of integrated, } \\
\text { effective, and efficient local } \\
\text { government governance }\end{array}$ \\
\hline & Smart Branding & $\begin{array}{l}\text { Revitalization of the } \\
\text { Citra Niaga area }\end{array}$ & $\begin{array}{c}\text { Availability of } \\
\text { architectural-based } \\
\text { landmark development } \\
\text { plans and local } \\
\text { wisdom }\end{array}$ & $\begin{array}{c}\text { Restoring the image of } \\
\text { Commerce as one of the icons of } \\
\text { Samarinda City }\end{array}$ \\
\hline 3 & Smart Economy & $\begin{array}{l}\text { Developing Samarinda } \\
\text { City Market Place }\end{array}$ & $\begin{array}{l}\text { Availability of an online } \\
\text { market for SMEs in } \\
\text { Samarinda City }\end{array}$ & $\begin{array}{c}\text { Expanding the market for } \\
\text { Samarinda City MSME products }\end{array}$ \\
\hline 4 & Smart Society & $\begin{array}{c}\text { Enabling public spaces } \\
\text { with community-based } \\
\text { activities }\end{array}$ & $\begin{array}{l}\text { Availability of public } \\
\text { space for the people of } \\
\text { Samarinda }\end{array}$ & $\begin{array}{l}\text { Availability of gathering and } \\
\text { recreation space for the people of } \\
\text { Samarinda }\end{array}$ \\
\hline 5 & Smart Living & $\begin{array}{l}\text { - E-parking } \\
\text { - Wifi corner }\end{array}$ & $\begin{array}{c}\text { Orderly parking } \\
\text { management in the } \\
\text { Citra Niaga area and } \\
\text { increasing connectivity } \\
\text { in public spaces }\end{array}$ & $\begin{array}{c}\text { Orderly parking area at Citra } \\
\text { Niaga and the availability of } \\
\text { internet network in the public } \\
\text { space area }\end{array}$ \\
\hline 6 & $\begin{array}{c}\text { Smart } \\
\text { Environment }\end{array}$ & E-waste Services & $\begin{array}{c}\text { Automatic waste } \\
\text { management that } \\
\text { integrates into related } \\
\text { SKPD }\end{array}$ & Integrated waste management \\
\hline
\end{tabular}

Source: Research Results Data, 2019.

At this time, in the Smart Governance Pillar, there is a work program, namely to integrate public services, and this is done with various programs, this is by the summary of the results of interviews with two research informants Mr. Suparmin, SE, M.Eng and Mr. Hendri Gunawan, S. Kom and adapted to the Samarinda Smart City 2019 - 2021 Blue Print document.

E-Warga is an online application that can be used by the people of Samarinda, which aims to facilitate the management of correspondence and business permits in the village. This application is provided in a mobile form that can be downloaded on smartphones (iOS and Android) and integrated with population data at the Population and Civil Registration Service through the samarindakota.go.id application.

SIKDA (Regional Health Information System) Samarinda City is an information system built by the Samarinda City Health Office for health services, consisting of several integrated sub-systems. Since being introduced to the public, from December 28, 2015, until July 15, 2018 , SIKDA Samarinda has been accessed by 723,549 people from both inside and outside the city of Samarinda.

Application of convenience permission in the city Samarinda is aimed at attracting both domestic and foreign investment. Various online licensing services have been implemented by the One-Stop Integrated Licensing and Investment Service (DPMPTSP), including 
HANCAPI (Reliable, Competent, and Innovative), SYAHARIE JAANG (One-Stop Licensing Service System Can Be Taken Home Immediately), and SMS (Sunday Morning). Service / Sunday Morning Service). In 2018 DPMPTSP implemented electronic signatures on documents permission published.

Residential document services in Samarinda City have been directed online and are integrated with village and health services. The online population document service can be effective and time-efficient because it makes it easier for the bureaucracy to make the process so that the document can be completed in one day. The LASKAR Two in One, Three In One program is an innovative program that is in line with the "Single Identity" program launched by the Central Government.

A Public Service Mall has been established at the Investment Office, and Permissions One-Stop Integrated to support services. The Kominfo Service has helped create an online queue at the public service mall and the population and civil registration service at the Population and Civil Registry Service to make the service easier.

Service 112 is a public service in the form of an Emergency Call Number (NPD) launched in October 2019. This service will integrate all emergency complaints from all Regional Rapid Response Units (URC). Emergency services and public complaints will be received by officers who picket in the Command Center room of Diskominfo.

In addition to the effectiveness of public services, programs in Smart Governance are also directed at increasing the accountability of government agencies' performance. Each government agency is required to complete the LAKIP and is assessed by the Central Government. There was an increase in the LAKIP assessment from 2017 to B predicate.

This Smart City Program also still has obstacles, among other things; the realization of Samarinda Smart City is the lack of socialization and is not supported by an adequate Regional Revenue and Expenditure Budget (APBD). Although discussions about Samarinda Smart City have been echoed since 2017 and the legal basis and master plan for the program have been made, for the past two years, the proposal for funds for Smart City has not been included in the budget priorities of Samarinda City. Samarinda City's budget allocation is still often aimed at building infrastructure that does not stick with the smart city idea. In addition, another problem that is also a crucial problem is regarding the communication of this Smart City program, both within the government apparatus and to the wider public, namely the people of Samarinda City.

Based on the interviews with informants, Novi Mediani as the owner of a Local Brand business in the fashion field "Jukut," stated that she often participates in FGD forums organized by the Regional Government, including those related to the Smart City Program. Clarification of the Magnificent Samarinda logo with its contractors, the results are not clear because the contractor only works on the given project. The continuation of the project is handed over to the Samarinda City Government. The movement of the Smart City Program is not too significant. Meanwhile, Dr. Rina Juwita, S.IP, M.HRIR (Academic / Lecturer in Communication Studies Program) argued that the Smart City concept of Samarinda City focuses more on Waterfront City Development. In this case, beautifying the "Face of the City" is a top priority because of its relation to attracting tourism and City Branding; it is just that there are very substantive problems that should be made a priority scale in handling and should be a priority scale at this time in the Smart City program of Samarinda City, for example, problems environment, waste, and flooding.

In the concept of communication planning, it is stated that communication planning is a written document that describes what must be done related to communication of achieving goals, in what ways can be done so those goals can be achieved, and to whom the communication program is addressed with equipment and in what period. How long it has been achieved, and how to measure (evaluate) the results obtained from the program (Robin Mehall) in Canara (2013: 45). Communication planning contains strategic planning and operational planning; this is included in the communication planning of the Samarinda City Smart City Program.

The discussion about the Samarinda City Smart City program plan is not short but has been carried out since 2016 until it was finally made in the Samarinda Smart City Master 
plan. This means that at the research stage, situation analysis, the formulation of program objectives have been carried out comprehensively by looking at various factors, including strengths, weaknesses, opportunities, and threats.

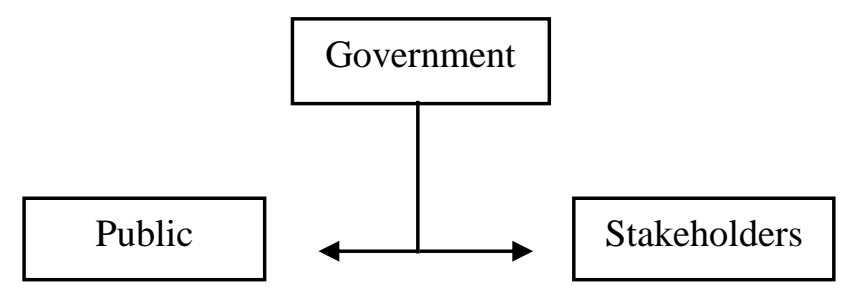

Figure 1 - The target audience of a smart city program

In the Samarinda City Smart City Program, the target audience is the Government, the wider community, other stakeholders such as companies, MSMEs, investors, communities that are part of the community itself. A city can be called a smart city or Smart City if it has been integrating information and communication technology to some extent in the day-to-day governance and operational processes. The technology integration is intended to increase efficiency, provide information to the public, improve services to the community or improve the welfare of citizens. The Smart City Program in Samarinda City can be said that the target audience is not ready as a whole, both in government officials and the community itself. Understanding of Smart City within the Samarinda City Government Apparatus is still very minimal. However, communication and information technology networks are starting to be integrated into all City Government agencies. The readiness of the City Government apparatus plays an important role because Smart Governance is a reference in the implementation of the Smart City Program as a whole. Smart Governance planning is the spearhead in planning Smart City Syctl (2015) in Annisah (2017:63).

In the objective formulation stage, it is known that in the long term, it is directed to realize Samarinda as a Smart and Leading Edge City in the Kalimantan Region, which then shared in several phases, namely planning the Samarinda Smart City master plan in 2017, the establishment of the Samarinda Smart City Quick Win program in 2018, the first phase of implementation (2017-2021), and the second phase of implementation (2021-2025). In the Quick Win Samarinda Smart City program, the main focus in the first phase of the program is integrating public services and the revitalization of Citra Niaga. If referring back to the communication planning model according to Assisi \& French regarding situation analysis, and also referring to Utomo and Hariadi's review in their research regarding the need for a need assessment in the Smart City program, it can be said that the crucial problems that occur in Samarinda City are environmental problems such as flood and garbage so that the Smart City program in the first stage should refer to handling the problem strategically.

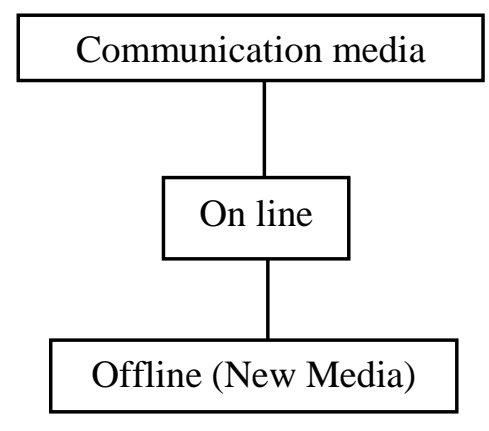

Figure 2 - Communication Media

At the stage of selecting communication media, choosing communication messages, and media production, there are many communication media used to disseminate information. Cooperation with various local media for online and offline publications and the 
use of social media through accounts on Facebook and Instagram owned by the City Government is also maximized to reach the audience. In this regard, there is a big question regarding the effectiveness of communication to the public. Although public research has not been carried out, from interviews with the community, it is stated that the socialization of the Smart City program in Samarinda City is still minimal; this can be seen from the lack of public understanding about the smart city itself.

In addition to conventional media, new media is used as a communication medium to maximize the spread of messages to the target audience. In addition, in the current era of information disclosure, new media is a must. In addition to providing convenience in disseminating messages, new media also allows users to interact and respond quickly in solving problems related to public services. Other media used in optimizing the socialization of the Smart City program are outdoor media, such as billboards, banners, backdrops, neons, boxes, and Videotron.

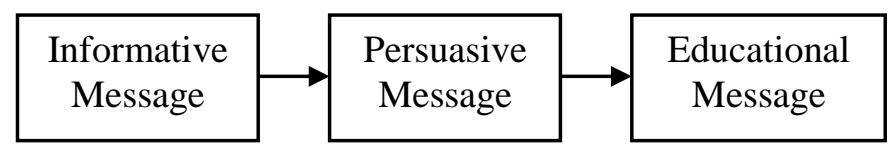

Figure 3 - Message development forms

Furthermore, it is necessary to develop messages in socialization; messages are all things conveyed by communicators in the form of symbols perceived and accepted by the audience in a series of meanings. The message is very dependent on the cold program delivered; if the program is commercial, then the nature of the message is persuasive and provocative. Meanwhile, if the program is oriented towards efforts to build public awareness, the nature of the message is persuasive and educative. Informative messages must be attached to all types of programs, whether commercial, political, counselling, public information programs. If it does not have an informative nature, a message will lead to misperceptions (Cangara, 2013: 114).

Concerning the message design developed in the smart city program, it combines the form of informative messages. For example, informative messages in the Smart City program are still categorized as new and actual programs, where program information echoes since 2016. Informative messages regarding Smart City programs are usually in the form of straight news, both in online and offline media. Persuasive messages, for example, form a persuasive message on the Samarinda City Government IG account @pemkot.samarinda, which contains an invitation to take part in the Samarinda City innovation competition. This activity is part of the activity towards a smart city, with the target of the competition being the Samarinda City government apparatus, especially at the OPD level. Besides that, the Hackathon is a competition for programmer activists to welcome Samarinda Smart City, where application providers compete to create applications that facilitate public services. In the Hackathon 2.0 activity with the theme Smart Citra Niaga, where the public is invited to be involved in the revitalization of Citra Niaga, which is one of the programs in the Samarinda City Smart City program, and educational messages, for example.

The purpose of using educational messages in the Smart City program in Samarinda City is to provide a thorough understanding of the entire audience, both at the level of knowledge and audience behavior. Moreover, educational messages, for example, concerning the Smart City program in Samarinda City, educational messages are carried out in various forms of activities, such as seminars, counseling, socialization, technical guidance, and training. Then, in addition to developing messages, it is necessary to have action and communication program management in Smart City. Samarinda City must communicate work programs on the six pillars of Smart City to a wide audience, both internally and externally. For example, in public service applications such as E-citizens, E-Kelurahan, LASKAR, and various other public service applications, although the application is ready to be used, the community needs to participate actively to get used to using the application. Another example of program management is the smart economy pillar. The programs 
focused on developing MSMEs by developing digital-based local brand product marketing strategies through the "samarindamart.id" marketplace. To maximize marketing through the marketplace, the thing that must be done is to promote the marketplace to increase visitor traffic.

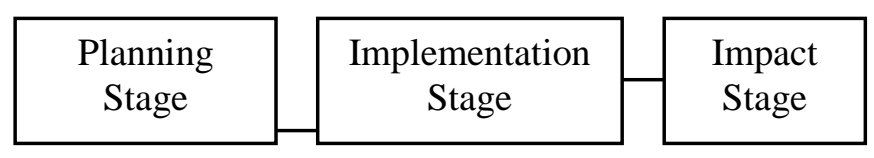

Figure 4 - Monitoring and evaluation stages

The last significant monitoring and evaluation of the communication program must be carried out based on scientific measurements of increasing awareness or changing the audience's opinions, attitudes, and behavior. The monitoring and evaluation must touch on three main stages: the preparation stage, the implementation stage, and the impact or effect stage (Morissan, 2008: 226). The Government has not determined how the monitoring and evaluation scheme is strategically related to the Samarinda City Smart City program.

Therefore monitoring and evaluation planning with three stages according to (Morissan 2008: 226), namely, there is a preparation stage, namely how to recognize the situation, seek information, approach and manage the program budget, Implementation Stage, namely knowing and carrying out activities that have been planned. First, and the impact stage, which is analyzing and evaluating the ongoing program, as well as evaluating the activities carried out by external and internal parties. to become a Smart City, continuous collaboration with all stakeholders is needed (Chourabi et al., 2012; Nam and Pardo, 2011; Hall et al., 2000). 2017: 4). In implementing the Smart City Samarinda program, it is necessary to open wide access to involve the whole community as one of the stakeholders. Many other cities in Indonesia or even other countries, in implementing Smart City invite their people to work together, especially young people, because, in the future, it will be young people (Millennials) who drive Smart City.

\section{CONCLUSION}

The Samarinda City Smart City Program focuses on six pillars of Smart City, namely Smart Governance, Smart Branding, Smart Environment, Smart Economy, Smart Living, and Smart Society.

The target audience for the Samarinda City Smart City Program is the City Government apparatus, the wider community, and stakeholders, including companies, investors, communities, academics, business actors, MSMEs. The dissemination of information messages about the Samarinda City Smart City Program is carried out through various media, both conventional and new media. In this case, communication effectiveness cannot be said to be maximal because there is still a lack of public understanding about Smart City.

The planning stage of program management relates to the optimal management of action programs and communication programs. The communication program should be able to support the action program. The management of action and communication programs in the Smart City of Samarinda City must communicate work programs on the six pillars of Smart City to a wide audience, both internally and externally. At the monitoring and evaluation stage, the Smart City program needs to be made in 3 stages: at the planning stage, at the implementation stage, and the impact stage. The Government has not determined how the monitoring and evaluation scheme is strategically related to the Samarinda City Smart City program.

In this program, audience research is needed to conduct an in-depth analysis of the level of readiness of the target audience as recipients of the Smart City program, and a communication campaign is carried out to build public awareness and audience participation regarding the Smart City Program as well as improved coordination between Regional Apparatus Organizations (OPD) of Samarinda City in planning and implementing the Smart City Program as well as socialization to all levels of society so that people understand and 
are familiar with digital-based forms of public services such as the objectives of the Samarinda Smart City program.

\section{REFERENCES}

1. Annisah., 2017, Proposed Smart City Planning: Smart Governance of Mukomuko Local Government, Journal of Telematics and Information Society Volume: 8 No.1 (JanuarySeptember 2017).

2. Canara, Hatfield., 2013, Communication Planning \& Strategy, Rajagrafindo Persada, Jakarta.

3. Devata, Evita., 2017, Steps Towards 100 Smart Cities, https://kominfo.go.id/content/detail/11656/step-menuju-100-smart-city/0/sorotan_media, accessed on June 1, 2019.

4. Effendy, Onong Uchjana., 2013, Communication Dynamics, Youth Rosdakarya, Bandung.

5. Dawn, Marhaeni. 2009. Communication Science: Theory and Practice. Yogyakarta: Graha IImu.

6. Haryanvi, Rosiana., 2018, What is the Development of Smart City in Indonesia?, https://properti.kompas.com/read/2018/11/09/200823221/like-apa-perkembangan-smartcity-di-indonesia?page=all).

7. https://diskominfo.kaltimprov.go.id/concept-smart-province-kalimantan-timur/, accessed on June 9, 2019.

8. These Cities in Indonesia Have Implemented Smart Cities, https://inixindojogja.co.id/kotakota-di-indonesia-ini-already-implementing-smart-city/, accessed on September 21, 2019

9. Master Plan Samarinda Smart City 2017-2025.

10. Morissan. 2008. Public Relations Management: Strategies to Become a Professional Public Relations. Jakarta: Kencana.

11. Novianti, Kurnia., Syahid, Choirunisa Noor., 2017, Towards a Smart City: Lessons from the Smart City Concept Applied in Jakarta and Surabaya, Dissemination of the research entitled "Community Participation on Smart City Development: Case of Japan and Indonesia" funded by The Sumitomo Foundation.

12. Nazir, Fritz Akhmad., 2015, Smart People Smart Mobility. The concept of a smart city that relies on society and its movement in the city of Metro,https://www.researchgate.net/publication/281614890

13. Mayor Regulation No. 8 of 2018.

14. Samarinda Smart City Program Lacks Socialization and is Not Supported by the Regional Budget, $\quad \mathrm{https://kaltimtoday.co/utama/kaltim/program-smart-city-samarinda-less-}$ socialization-dan-not-supported-apbd, accessed on June 9, 2019.

15. Riyanto, Adi., Mostofa, Haris,. 2017, Implementation of the Smart City Concept in Environmental Aspects Case Study: Cimahi City, Proceedings of the 2017 Annual National Seminar on Mathematics and Science and Technology, Open University Convention Center.

16. Satori, Djam'an., Komariah, Aan., 2014, Qualitative Research Methodology, Alfabeta Publishers, Bandung.

17. Utomo, Shandra Eko Wahyudi., Hariadi, Mochammad., 2016, Smart City Development Strategy and its Challenges for City Communities, Journal of Strategy and Business Vol. 4 No. 2. 